\title{
Isolated Hemolysis Profile of Streptococcus Sp. Isolation Result from Swine's Tonsil In Slaughter House at Punggul and Bongkasa Village
}

\author{
Carene Naomi $^{1}$, I Wayan Suardana ${ }^{2}$, I Nyoman Suarsana ${ }^{3}$ \\ ${ }^{1}$ Udayana University Veterinary Medicine Student \\ ${ }^{2}$ Veterinary Public Health Laboratory Veterinary Medicineof Udayana University \\ ${ }^{3}$ Microbiology Clinic Laboratory Veterinary Medicine of Udayana University \\ P.B Sudirman Street, Denpasar, Bali, Indonesia. \\ *Corresponding Author: carenenaomi96@gmail.com
}

\begin{abstract}
Streptococcus is a Gram-positive coccus from the family Streptococcaceae that can be found normally in some healthy animal but can cause a disease as well. The purpose of this research is to know the hemolysis profile from pig's tonsil swab isolated from the traditional pig slaughterhouse at Punggul Village and Bongkasa Village that can be divided into three hemolytic profile; alpha-hemolytic, beta hemolytic, and gamma hemolytic, to know the pathogenicity. This research is divided into several steps, such as; isolating the swab, Gram test, catalase test, oxidase test, and hemolysis test on Sheep Blood Agar. Streptococcus is a Gram-positive coccus, tested Gram positive, catalase negative and oxidase positive. This research concludes the amount of positive Streptococcus sp sample based on hemolysis profile is 6 of 24 samples, whereas 3 of 24 samples $(12,5 \%)$ has $\alpha$ hemolysis pattern, 3 of 24 samples $(12,5 \%)$ has $\beta$ hemolysis pattern and none showed the $\gamma$ pattern. The conclusion from the table; showed positive sample of Streptococcus sp is divided 50:50 for the $\alpha$ and $\beta$ hemolysis, and no sample showed the $\gamma$ pattern. At most cases, the $\alpha$ and $\beta$ hemolysis Streptococcus is a pathogen bacterium. This data might be useful for references to see the transmission of Streptococcus sp in swine at Abiansemal area in Badung, Bali.
\end{abstract}

Keywords: Streptococcus sp, Pig, Swine, Hemolysis, Abiansemal

\section{INTRODUCTION}

Streptococcosis is a term used for disease caused by a group of bacteria called Streptococcus. Some of this bacterium are normal flora living in the human and animal's body and don't cause disease. On the other hand, some of them can cause disease (sometimes severe one) both in animal and human. One of the animals that likely to get Streptococcosis is swine. The bacteria itself is a normal flora, but when the bacteria enter wound, abrasion, or other wound or when the immune system is weakened, disease can occur. This bacterium spread between animal by direct contact, aerosol, vomit and sometimes ingested/oral [6].

Is it known that Streptococcus pathogenic strain have several virulence factor such as carbohydrate antigen and specific protein, toxin production and enzyme [7]. According to The Center of Food Safety and Public Health at 2006, some of clinical identification from 
Streptococcus is based on their hemolysis reaction in blood agar and Lancefield grouping. There is three types of hemolysis: alpha, beta, and gamma. Streptococci alpha hemolytic makes partial hemolysis or greening around the colony, linked to red blood cell hemoglobin reduction. This bacterium usually causes acute streptococcal disease. Gamma hemolysis is a term used for non-hemolysis colony. In many cases, to limit the differences between alpha and gamma hemolytic, many species can be called as non beta hemolytic. Streptococcus group that can break red blood cell and release hemoglobin perfectly counted as type B hemolytic [3].

There are many Streptococcus $s p$ 's species living in healthy pig's tonsil, nasal cavity, feces, and their genital tract. Looking at Bali's culture, almost all household raise pigs, it can't be denied that people's nescience at swine related disease and poor pork processing can affect poorly at tourism industry in Bali because one of the tourism attractions for domestic and foreigner in Bali is in the culinary section. Therefore, isolated hemolysis profile from swine tonsil in the plague location because one of Streptococcus sp's species research is expected to contribute in preventing Streptococcus sp.'s further deployment and decrease people and tourist's concern on consuming pork processed cuisine in Bali.

\section{RESEARCH METHODS}

\section{Research Tools and Material}

Tools used for this study are sterile plastic as sample container, autoclave, refrigerator, cool box, scale, Erlenmeyer, Beker glass, test tube shelf, petri dish, micropipette, needle ose, circle ose, Bunsen fire, stirring stick, vortex, and centrifugate. Material used for this study are isolated pig swine sample swab, Sheep Blood Agar media, Gram staining material, BHI media, oxidase paper strip, alcohol, and $\mathrm{H}_{2} \mathrm{O}_{2} 3 \%$ liquid.

\section{Isolating Streptococcus sp}

Isolating Streptococcus sp. was done in Blood Agar in microaerophilic condition with 1 sachet of gas generating kit added to the box. Sample was incubated for $24-48$ hours at $37^{\circ} \mathrm{C}$.

\section{Gram Staining}

Streptococci is the general term for a diverse collection of Gram-positive cocci that typically grow as chains or pairs. The isolated bacteria are stained by crystal violet. The addition of iodine forms a complex within the cell wall. Addition of a decolorizer removes the stain from gram-negative organisms due to their increased lipid content. These cells are stained pink with the counter stain safranin and then washed. The result can be seen on the microscope to be observed further for the morphology and the color.

\section{Catalase Test}

Hydrogen peroxide is used $\left(\mathrm{H}_{2} \mathrm{O}_{2}\right)$ to determine if bacteria produce the enzyme catalase. The catalase test is performed by adding hydrogen peroxide and observing for effervescence (bubbling) which indicates a positive test. This test is performed to differentiate between Streptococcus and Staphylococcus.

\section{Oxidase Test}

Streptococcus sp's identification is done by oxidase test. One swab of bacteria colony that grows in Nutrient 
Agar is taken and moved to the oxidase paper. Positive result shows color changes on the paper showing dark purple color in 5-10 seconds.

\section{Hemolysis Test}

The bacteria that has been isolated and identified is grown in blood agar medium, incubated for 24 hours at $37^{\circ} \mathrm{C}$. Hemolysis type is observed on the growing colony. The three major types of hemolysis are $\beta$ hemolysis, $\alpha$ hemolysis, and $\gamma$ hemolysis. Hemolysis reaction is useful to differentiate Streptococcus's species. With hemolysis reaction on the medium culture and the help of clinical data makes clinician's job easier to diagnose infectious disease especially by $S$. betahaemolitycus [5]. This hemolysis test can help understanding pathogenicity potential of Streptococcus sp.

There are three types of hemolysis: beta, alpha and gamma hemolysis. Beta-hemolytic streptococci are those that completely lyse the red cells surrounding the colony. These bacteria tend to cause most acute streptococcal diseases, such as $S$. pyogenes and $S$. agalactiae. Alphahemolytic streptococci cause a partial or "greening" hemolysis around the colony, associated with the reduction of red cell hemoglobin, for example $S$. pneumoniae and $S$. viridans. Gamma-hemolysis is a term sometimes used for non-hemolytic colonies [4].

\section{Data Analysis}

The data is analyzed descriptively explaining isolated hemolysis profile of Streptococcus $s p$ from tonsil samples taken at slaughterhouse at Punggul and Bongkasa Village.

\section{RESULT AND DISCUSSION}

\section{Research Result}

Six pig tonsil's swabs taken from Punggul Village and eight samples from Bongkasa Village are grown into BA media and incubated for 24 - 48 hours for $37 \mathrm{C}$. From the growing period obtained 24 isolate colonies with difference characteristic to get Gram staining, catalase test, oxidase test, and hemolysis test afterwards.

\section{Gram Staining}

Gram staining is used to differentiate between Gram positive bacteria and Gram-negative bacteria and observed for the shape and order. From the Gram staining shows there are two different types; coccus and chained coccus. The result shows there are 11 purple coccus and 13 purple chained-like coccus. All of the 24 isolates were showing purple color meaning that the bacteria is Gram positive indeed because it has the ability to keep the purple color because it has thick peptidoglycan in the cell wall.

\section{Catalase Test}

Catalase test is a primary test used to find the activity of catalase enzyme in a bacterium. The result shows 6 isolates were tested negative and 18 were catalase positive. One of the bacteria that have catalase negative criteria is Streptococcus sp.

\section{Oxidase Test}

Suspected Streptococcus $s p$ that is catalase negative is observed further with 
oxidase test using the paper strip test. Oxidase test result shows 6 isolates were tested positive given the trait showing as color shifting to dark purple to black at the oxidase strip.

\section{Hemolysis Profile}

Swine's tonsil swab samples originally 14 samples taken from the pig Table 4.1.4 Conclusion of Tonsil's Isolate Hemolysis Profile Examination

\begin{tabular}{|c|c|c|c|c|c|c|}
\hline No & $\begin{array}{l}\text { Sample } \\
\text { Code }\end{array}$ & $\begin{array}{l}\text { Gram } \\
\text { Staining }\end{array}$ & Shape & $\begin{array}{l}\text { Catalase } \\
\text { Test }\end{array}$ & $\begin{array}{l}\text { Oxidase } \\
\text { Test }\end{array}$ & Hemolysis \\
\hline 1 & PT 1.1 & + & $\begin{array}{l}\text { Chained } \\
\text { coccus }\end{array}$ & - & + & Alpha \\
\hline 2 & PT 1.2 & + & $\begin{array}{l}\text { Chained } \\
\text { coccus }\end{array}$ & - & + & Beta \\
\hline 3 & PT 2.1 & + & Coccus & - & + & Alpha \\
\hline 4 & BKT 8.2 & + & Coccus & - & + & Beta \\
\hline 5 & BKT 10.2 & + & $\begin{array}{l}\text { Chained } \\
\text { coccus }\end{array}$ & - & + & Beta \\
\hline 6 & BKT 12.1 & + & Coccus & - & + & Alpha \\
\hline
\end{tabular}

Table 4.1.4 shows that all of 6 isolates tested Gram positive, shaped either coccus or chained-like coccus, catalase negative, and oxidase positive; 3 isolates makes $\alpha$ hemolysis pattern, 3 isolates makes $\beta$ hemolysis pattern, and none showed $\gamma$ hemolysis pattern. $\alpha$ slaughterhouse at Punggul and Bongkasa Village, Abiansemal, Badung, was isolated into $\mathrm{BA}$ to find the hemolysis profile. The result shows 24 isolates with different characteristic. The bacteria identification result shows in Table 4.1.4 below.

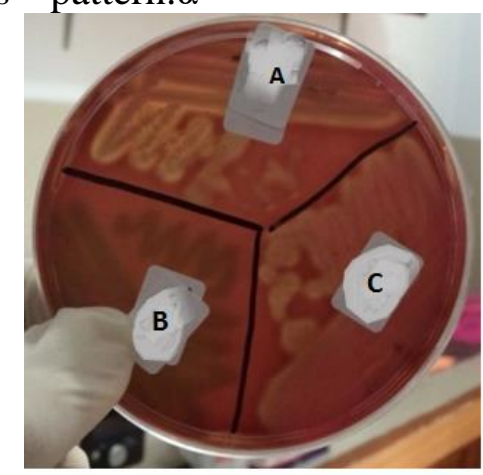

Figure. 4 Hemolysis Test Result

Explanation: $\mathrm{A}=\beta$ hemolysis, $\mathrm{B}=\alpha$ hemolysis, $\mathrm{C}=\alpha$ hemolysis. 


\section{Streptococcus sp Positive Result Percentage Based on Hemolysis Pattern}

From the research that originally used 14 swine tonsil's swab from the slaughterhouse at Punggul and Bongkasa Village, Abiansemal, Badung, and then grown into BA then obtained 24 samples, positive result of Streptococcus $s p$ based on hemolysis pattern in percentage as follows; positive samples of Streptococcus $s p$ that is tested Gram positive, catalase negative, and oxidase positive as much 6 of 24 samples, as 3 samples $(12,5 \%)$ is $\alpha$ hemolysis, 3 samples $(12,5 \%)$ is $\beta$ hemolysis, and none of the samples is $\gamma$ hemolysis. Summed up from the table showing positive sample of Streptococcus spare evenly divided for $\alpha$ and $\beta$ hemolysis with the ratio 50:50, and none showed $\gamma$ hemolysis pattern.

\section{Discussion}

Lysing ability of Streptococcus to break down red blood cell is one of the ways to differentiate for other biochemical test, because hemolysis ability is estimation test for some Streptococcus. On the other hand, Streptococcus's strain for hemolysis is always linked to the pathogen infection ability [8], [1], [2].

Streptococcus $\alpha$ hemolytic is a Mitis group that consist of several species that is Str. pneumoniae, Str.mitis, Str. oralis, Str. sanguis, and Str. gordonii, and Anginosus group including Str. anginosus and Str. intermedius. The mitis group includes commensals of the human oral cavity and pharynx, although one of the species, Streptococcus pneumoniae, is also an important human pathogen. The anginosus group and the salivarius group are part

of the commensal microflora of the oral cavity andpharynx [4].

While for Streptococcus $\beta$ hemolytic is a Pyogenic phylogenic group that consist Str. pyogenes, Str. agalactiae, and Str. equisimilis (Killian, 2008). The pyogenic group includes most species that are overt pathogens of man and animals. The bovis group belongs in the colon. The mutans group of streptococci colonizes exclusively tooth surfaces of man and some animals; some species belonging to this cluster are involved in the development of dental caries [4].

\section{CONCLUSION}

Based on the result, the conclusion of this study is positive tested samples of Streptococcus sp based on the hemolysis profile is 6 of 24 samples $(25 \%)$ have lysing ability to break red blood cell with the detail as follow; 3 of 24 samples $(12,5 \%)$ is $\alpha$ hemolysis, 3 of 24 samples $(12,5 \%)$ is $\beta$ hemolysis, and no $\gamma$ hemolysis sample. Looking at pathogenicity potential, the odds of human consuming processed pork meat or cuisine that contain both of Streptococcus sp $\alpha$ hemolysis and $\beta$ hemolysis is still there $(25 \%)$, despite of the fact that the bacteria itself is a normal flora in the respiratory tract, however in some condition can cause disease both for human and animal, because both of the type $\alpha$ hemolysis and $\beta$ hemolysis tend to be pathogen. 


\section{SUGGESTION}

Further research needs to be done to find out Streptococcus sp's species type that has been isolated in this study because it's only limited to the hemolysis type only. Knowing the hemolysis type of Streptococcus $s p$ can help to understand which group can cause disease to human and animal, so there can be prevention in the future.

\section{REFERENCES}

[1] Brooks G.F, S. Butel and SA Morse 2002. Jawetz, Melnick \& Adelberg's Mikrobiologi

Kedokteran (Medical Microbiology). Ed. 1. Penerjemah dan Editor Bagian Mikrobiologi Fakultas Kedokteran Universitas Airlangga. Penerbit Salemba Medika.

[2] Hof, H and R. Dörries 2002. Medizinische Mikrobiologie. 2., Korrigierte Auflage. Georg Thieme Verlag Stuttgart.

[3] Jawetz, E., Melnick, J. L., Adelberg, E. A., 1986, Mikrobiologi Kedokteran, diterjemahkan oleh Bagian Mikrobiologi Fakultas Kedokteran Universitas Airlangga, 205-209, Penerbit Salemba Medika, Jakarta
[4] Killian,M. 2008. Topley and Wilson's Microbiology andMicrobial Infections, 9th edition, Volume 2. London, pp. 633-667.

[5] Mudatsir; Zulfitri; dan Husna. 1999. Penggunaan Beberapa Mediumuntuk Isolasi dan IdentifikasiEnterococcus faecalis dan Pola Kepekaannya Terhadap BeberapaAntibiotik. Lembaga Penelitian Universitas Syiah Kuala. Banda Aceh.

[6] The Center Food Safety and Public Health, "CFSPH Technical Fact Sheets. Streptococcosis", The Center Food Safety and Public Health Iowa University, http://www.cfsph.iastate.edu/Dise aseInfo/default.html(diakses 21 Januari 2018).

[7] Vecht U, Arends JP, van der Molen EJ, van Leegoed LAMG. 1989. Differences in Virulence Between Two Strain of Streptococcus suis Type II After Experimentally Induced Infection of Newborn Germ-Free Pigs. Am. J.Vet. Res. 50 (7) 1037-1039

[8] Wibawan IWT and Laemmler 1990. Propeties of Group $\beta$ streptococci With Protein Surface antigens $X$ and $R$. J. Clin. Microbiol. (28): 2834-2836. 